\title{
WATER BALANCE ESTIMATION IN ANTHEMOUNTAS RIVER BASIN AND CORRELATION WITH UNDERGROUND WATER LEVEL
}

\author{
I. FIKOS* \\ G. ZIANKAS \\ A. RIZOPOULOU \\ S. FAMELLOS
}

Selected from papers presented in $9^{\text {th }}$ International Conference on Environmental Science and Technology (9CEST2005)

1-3 September 2005, Rhodes island, Greece
ANATOLIKI S.A.

Development Agency of Eastern Thessaloniki

K. Rafailidi 3, Thermi, 57001, Greece

*to whom all correspondence should be addressed e-mail: ifikos@anatoliki.gr

\section{ABSTRACT}

Estimation of annual water balance is critical for water management and developmental planning in the area of Anthemountas river basin. In the framework of LIFE04/ENV/GR/000099 project and in continuance to prior projects in the area, the average annual water balance was estimated using the annual precipitation and water consumption. The statistic relationship between elevation and precipitation measured at different stations in the greater area, was applied to the Digital Elevation Model (DEM) (accuracy 20X20m) and the spatial distribution of annual precipitation is calculated for the Anthemountas river basin. Consumption of underground water was analytically calculated based on the different types of agricultural activities as annually reported by the Ministry of Agriculture. The Domestic water consumption was also calculated. Evaportranspiration is estimated analytically using two different methods (Thorthwaite's and Turk's). Both methods gave similar results.

Moreover the spatial distribution of infiltration and runoff coefficients were calculated taking into consideration the different geological features, since they determine the maximum value of the infiltration coefficient, and the CORINE land coverage classification assuming no infiltration at builded areas. All the above were calculated and presented in raster format using the ESRI ArcGIS 9 environment.

The correlation between the negative water balance and the drop of the underground water level, as this was pictured through underground water level measurements in the past decade, was discussed and evaluated. To further understand the relationship between the negative water balance and the spatial distribution of the underground water level drop, the most consuming wells in the Anthemountas river basin are distributed and categorized based on consumption estimates.

Future work should assess more precise land coverage dataset in order to produce spatial distribution of evaportranspiration. At the same time, precise precipitation datasets, that will be produced by the meteorological monitoring network, that is to be established in the LIFE04/ENV/GR/000099 project framework, will provide more accurate estimates of precipitation distribution. This will lead to the determination of more accurate estimates for both infiltration and runoff in the basin. Data monitoring, assessment and water balance estimation are valuable tools in a step-by-step procedure towards the achievement of sustainable use of water in the river basin of Anthemountas.

KEYWORDS: Anthemountas river basin, water balance, infiltration, GIS, underground water level measurements, sustainable use 


\section{INTRODUCTION}

Anthemountas river basin is situated in Macedonia, in the northern part of Greece. It is the northwest part of the Chalkidiki peninsula (figure 1) covering $318 \mathrm{Km}^{2}$. It consists of two main sub basins, Basilika sub basin $\left(208 \mathrm{Km}^{2}\right)$ which occupies the lower parts of the basin and Galatista sub basin $\left(110 \mathrm{Km}^{2}\right)$, which is situated higher. A dense well-formed stream network drains the area while the geological features include a large variety of different sediments combined with various rocks. Apart from that the existence of Anthemountas fault, a number of smaller parallel and vertical faults and geothermal activity make the geology of the area complicated. The hydrogeology, consequently, presents complex features (confined, semi-confined and hanging aquifers).

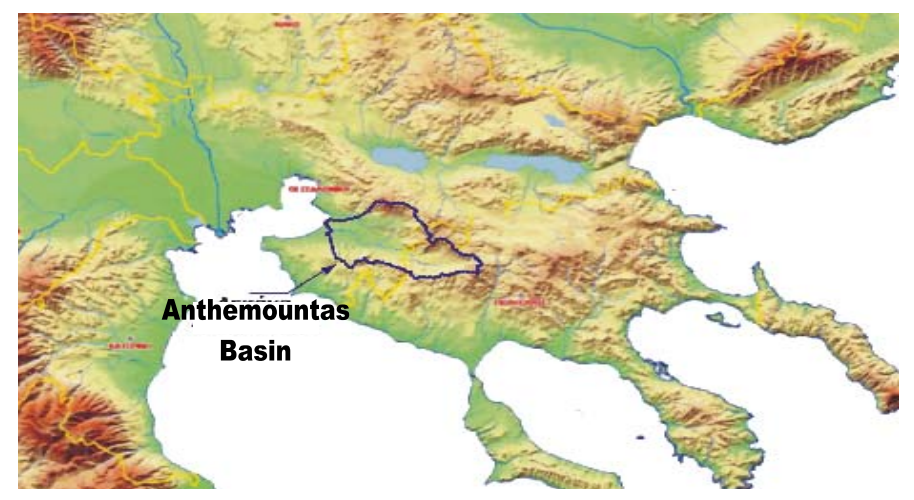

Figure 1. Anthemountas river basin

The river basin is near to the city of Thessaloniki and therefore is being pressured by the constantly increasing population as is shown in table 1 . Many different human activities are hosted in the area resulting to increased demand for water of good quality or quantity or both.

Table 1. Population in the river basin

\begin{tabular}{|l|l|l|l|}
\hline $\begin{array}{l}\text { Municipallity/ } \\
\text { Community }\end{array}$ & 1991 & 2001 & $\%$ \\
\hline Thermi & 9132 & 16546 & 81,2 \\
\hline Basilika & 7269 & 9303 & 28 \\
\hline Galatista & 2711 & 2974 & 9,7 \\
\hline Galarinos & 261 & 299 & 14,6 \\
\hline
\end{tabular}

The Region of Central Macedonia began an effort to examine the area some years ago with a series of projects aiming to protecting the quantity and quality of the water bodies. In this effort, ANATOLIKI S.A. 'Development Agency of Eastern Thessaloniki' has undertaken many initiatives with the last one resulting to the approval of the LIFE04/ENV/GR/000099 project that is aiming to the pilot implementation of the WFD in Anthemountas river basin. The project started in October 2004 and will last 3 years.

\section{ANNUAL WATER BALANCE}

The first issue that should be studied in the effort of achieving sustainable water management is, understanding the annual water balance in the basin. This means finding out how much water comes into the system and then finding out where that water goes. Either infiltrates to the ground renewing underground water bodies or runs off to end up to the sea while a significant percentage evaporates and returns to the atmosphere.

Precipitation $\mathrm{P}$. In the case of Anthemountas river basin, precipitation is the only way that water comes into the system. Unfortunately, as is usually the case, there are not many stations monitoring the precipitation in the area. Therefore in our study we used stations that are situated in the broader area and at various altitudes. In order to obtain a 
relationship between precipitation $\mathbf{P}$ and altitude we calculated mean average precipitation per month and then per year. We then calculated the following equation (1) that describes how precipitation changes with altitude

$$
Y=4^{*} 10^{-9} X^{3}-4^{*} 10^{-6}{ }^{*} X^{2}+0,0013 X+0,4265 \quad \text { with } R^{2}=0,95
$$

The above equation was applied to the digital elevation model (DEM) with cell size 20 by 20 meters resulting to a spatial distribution model for the annual precipitation in the basin (figure 2). The total annual precipitation was easily calculated as the volume integral of the surface described above: $P=180,129 \times 10^{6} \mathrm{~m}^{3} /$ year

Evaportranspiration $\mathrm{E}$. In order to calculate the amount of the precipitation that evaporates or transpires back to the atmosphere we used the two most common and generally accepted methods proposed by Turk (1951) and by Thornthwaite and Mather (1955). Turk's method produced average annual true evaportranspiration equal to E1=461,73 $\mathrm{mm}$ while Thornthwaite's - Mather's method resulted to E2 $=457 \mathrm{~mm}$.

Since the two methods gave similar results we chose to use $\mathbf{E}=\mathbf{4 5 7} \mathrm{mm}$ as the mean annual evaportranspiration. To express this in terms of spatial distribution model we created a grid of cells with size equal to $20 \times 20 \mathrm{~m}$ and to each cell we attributed a value equal to $\mathrm{E}$ (Figure 2).

Infiltration - Runoff Calculating the total infiltration of a surface means calculating the infiltration coefficient for that surface. This is a very difficult task that requires the use of many parameters. Most of the parameters have not been studied for the broader area of Anthemountas and therefore we are obliged to use values and methods that describe the phenomenon with a certain degree of uncertainty. The parameters taken into consideration are:

- Geology: We digitized the geology by the official maps (1:50000) published by I.G.M.E. and to each different formation we attributed an infiltration coefficient $\mathbf{i}_{\mathbf{g}}$ (Soulios 1986). The values vary from $30 \%$ for calcareous rocks to $5 \%$ in hard metamorphic fractured rocks.

- Land coverage: because a part of the surface due to human activities is covered by constructions that prevent precipitation from reaching the ground we decided to use land coverage data published by CORINE96 in order to account for this areas and their negative effect to infiltration assuming coefficient $i_{\text {corine }}=\mathbf{0}$ in builded areas.

All the above factors where expressed in terms of spatial distribution (cells with size 20 by $20 \mathrm{~m}$ and unique value) and then with the help of a raster calculator we calculated the following equation that provides the final infiltration coefficient (Figure 2).

$$
I_{C}=i_{g} * i_{\text {corine, }} \text {, where } I_{C} \text { is the final infiltration coeficcient }
$$

Using this combined infiltration coefficient (expressed as a grid of distinct values) and multiplying it with the grid describing the spatial distribution of precipitation that we calculated earlier we obtained a new grid that describes how much water infiltrates annually in Anthemountas river basin (Figure 2). I=7,1 X10 $0^{6}$ cubic meters

Again the volume integral of this surface provides the total amount of water that infiltrates the ground leading to underground aquifer's recharge.

Water Consumption In Anthemountas river basin the total consumption can be distinguished to domestic, agricultural, pastoral and industrial. Each one of these categories were treated separately

- Domestic consumption: The lack of a rationally organized monitoring network anywhere in the studied area forced the use of statistically calculated averages. This averages where crosschecked in those cases where hydrometers were available. A total consumption of $4,347 \times 10^{6} \mathrm{~m}^{3} /$ year was calculated.

- Agricultural consumption: The annual databases of the prefectures of Thessaloniki and Chalkidiki were obtained and statistically processed. These were combined with the average annual needs for water that were evaluated for all the different kinds of agricultural activities in the area. This process produced a minimum need for 23,350 $\mathrm{X} 10^{6} \mathrm{~m}^{3} /$ year 
- Pastoral consumption: The total number of animal farming was calculated using the official licenses kept in the prefectures of Thessaloniki and Chalkidiki. Average consumption needs per animal, according to Greek legislation were used and a total of $301493 \mathrm{~m}^{3} /$ year was calculated.

- Industrial consumption: The only way to estimate the annual industrial needs in the basin was by using the license that each industrial unit is required to obtain according to legislation. These data processing resulted in an annual need for 1,57 $\mathrm{X} 10^{6} \mathrm{~m}^{3}$.

Though the authors understand that it's almost certain that the above calculations underestimate the true water consumption in Anthemountas river basin however the methodology used led as close to true consumption estimate as possible.

Comparison of the calculated total need for water in Anthemountas river basin with the calculated amount of water that infiltrates and recharges the underground aquifers shows an enormous lack of water in the basin.

\section{Infiltration - Consumption $\rightarrow 7,1 \times 10^{6}-29,6 \times 10^{6}=-22,5 \times 10^{6}$ cubic meters}

It is obvious that $22,5 \times 10^{6} \mathrm{~m}^{3}$ of water per year is pumped to cover the needs by the underground aquifers. This results in significant degradation of the water resources in the basin.

\section{IMPACT ON AQUIFER'S WATER LEVEL}

Due to the increased interest for development in Anthemountas river basin that was already happening in the early 90's the local authorities started focusing on monitoring the quantitative characteristics of the underground water bodies. The monitoring network focused on the characteristics of the Basilika sub basin. Few years later the network expanded to monitor the Galatista sub basin. Underground water level measurements are taken twice per year, once before the start of the wet season and once at the end of the wet season. In figure 3 the spatial distribution of the water level changes through the time period 1998 to 2004 is presented. The measurements prove that the water balance we calculated earlier is correct. This conclusion is drawn by the observed drop of the aquifer's water level in Basilika sub basin. The drop is not uniformly distributed in the full extent of the basin. There are areas where the observed drop is only one or two meters but at some areas the drop increases up to nine or ten meters. However the situation is different in the sub basin of Galatista, where it appears that the aquifer's recharging rate is fast enough to withstand the current pumping rate without signs of degradation.

In order to examine the correlation between the spatial distribution of water level changes and the pumping rate. To do this we plotted the total annual consumption for those wells that we managed to obtain data for (Nagoulis 1998, Latinopoulos 2001). Different diameter circles show different consumption. On the same figure we plotted all the wells that have been found in the area. The first thing that becomes obvious is that there are more wells in the sub basin of Basilika than in Galatista sub basin. The difference becomes even greater if we consider the fact that in Basilika sub basin the number of wells that remain unknown is assumed at least equal to those we know. Another fact that becomes clear is that there more wells that pump small quantities than wells that pump significant quantities (figure 4). The third and perhaps the most important observation is that the areas with significant drop of the aquifer's water level do not necessarily coincide with wells that are reported to pump great amounts of water. 


\section{RESULTS - CONCLUSIONS}

The annual water balance for Anthemountas river basin was evaluated taking into consideration all the parameters that could be evaluated. Emphasis was given on the calculation of the spatial distribution of precipitation and infiltration coefficient, resulting in a grid of unique values every 20 meters. In this way the water balance calculations along with the different 'levels' of information become more useful. It's easier for scientists to elaborate them working in various scales.

The calculations revealed a dramatic deficiency equal to $22,5 \times 10^{6} \mathrm{~m}^{3}$ per year in the water balance. Although the data contain uncertainties it is more than clear that the degradation revealed is a fact.

The same situation is revealed, qualitatively, by observations of the water level changes. The water level drop is taking place in extended areas, and although the data refer to a very narrow time window, the drop equals or is even more than 5 meters.

We observed that the drop of water level is not related with the existence of deep wells that pump large quantities of water when their density remains small. On the contrary it

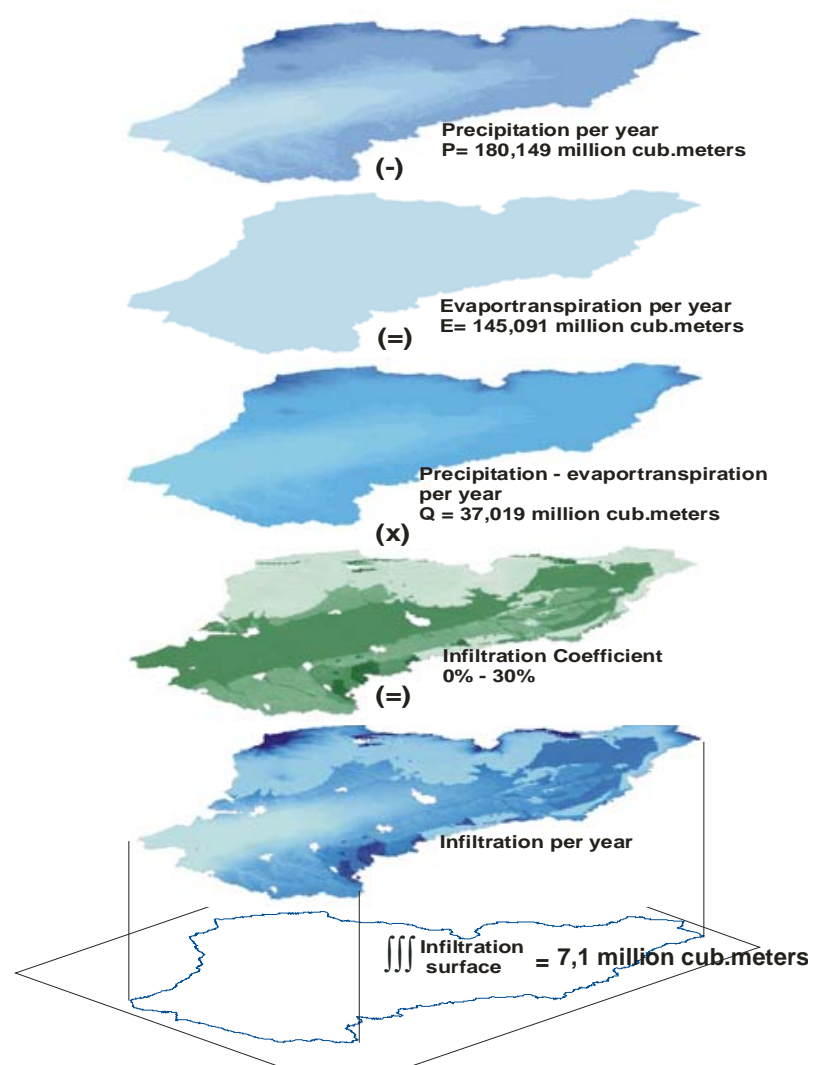

Figure 2. Schematic representation of the methodology used to calculate the total annual infiltration in Anthemountas river basin. The different levels of information used in the calculations can be seen (dark colors reveal higher values in all levels)

appears that a big number of wells pumping few thousand liters per year situated in small distance one from the other sums up to a much greater consumption. This conclusion indicates that preservation of the underground water resources should involve the encouragement for deep wells that will serve many needs rather than dense grid of small well that serve few. Moreover, water management task by the state authorities, as imposed by WFD and the Greek legislation becomes easier by adopting this policy.

The negative water balance requires that the state authorities, the local authorities and all the stakeholders of the area will get involved and along with scientists will take immediate action aiming to protect the underground water resources of the basin. 
In the immediate future focus should be placed upon creating an adequate hydrological monitoring network along with an adequate meteorological network. Critical for the evaluation of a more precise water balance for Anthemountas river basin is the creation of an updated edaphological map that will provide precise information on the type of ground, thickness and hydraulic behavior in the basin. Finally an extended hydrogeological - geophysical survey will provide useful information on the true extent of the aquifers, and their recharging process.

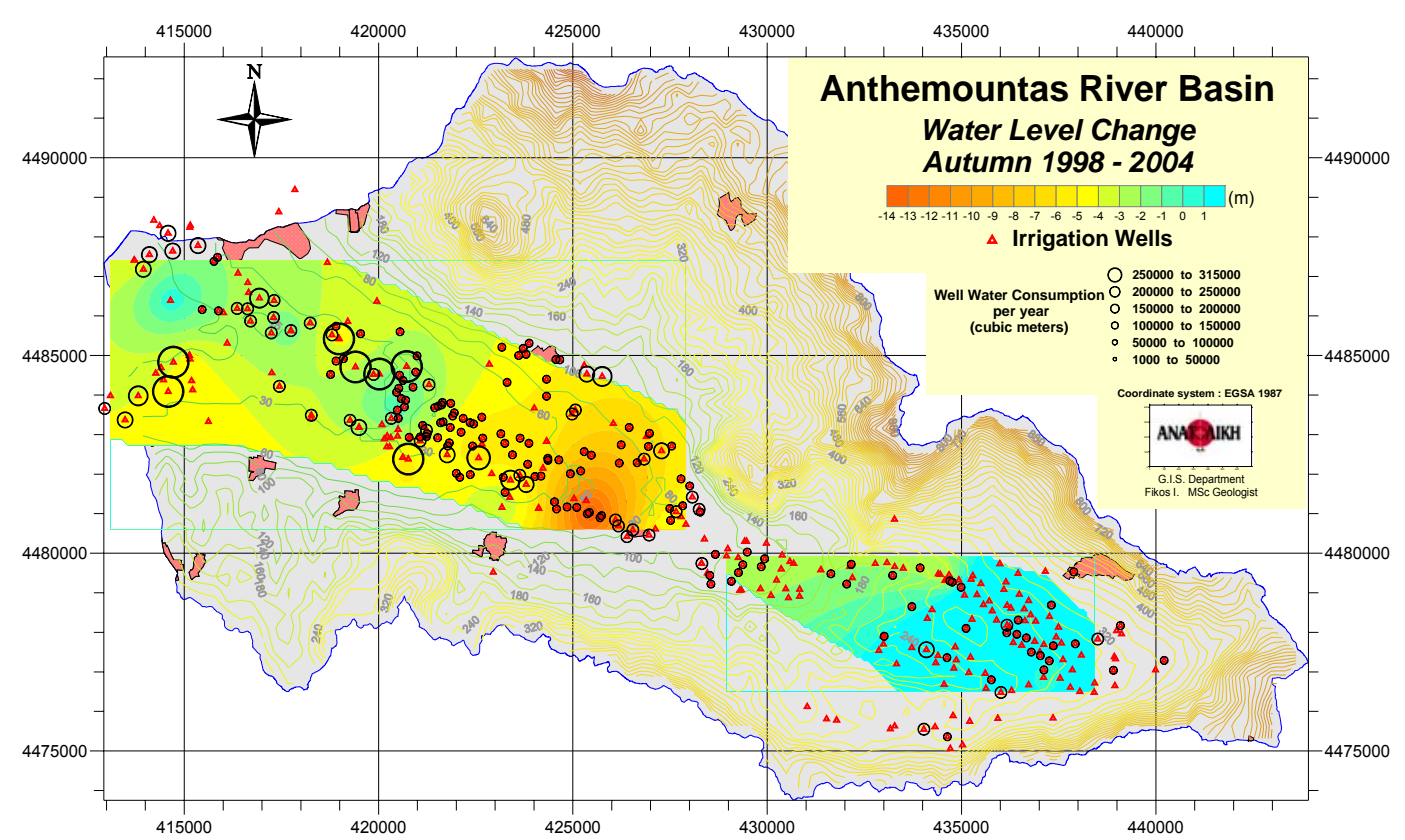

Figure 3. Comparison of the observed changes in the underground water level with water pumped by the aquifer annually

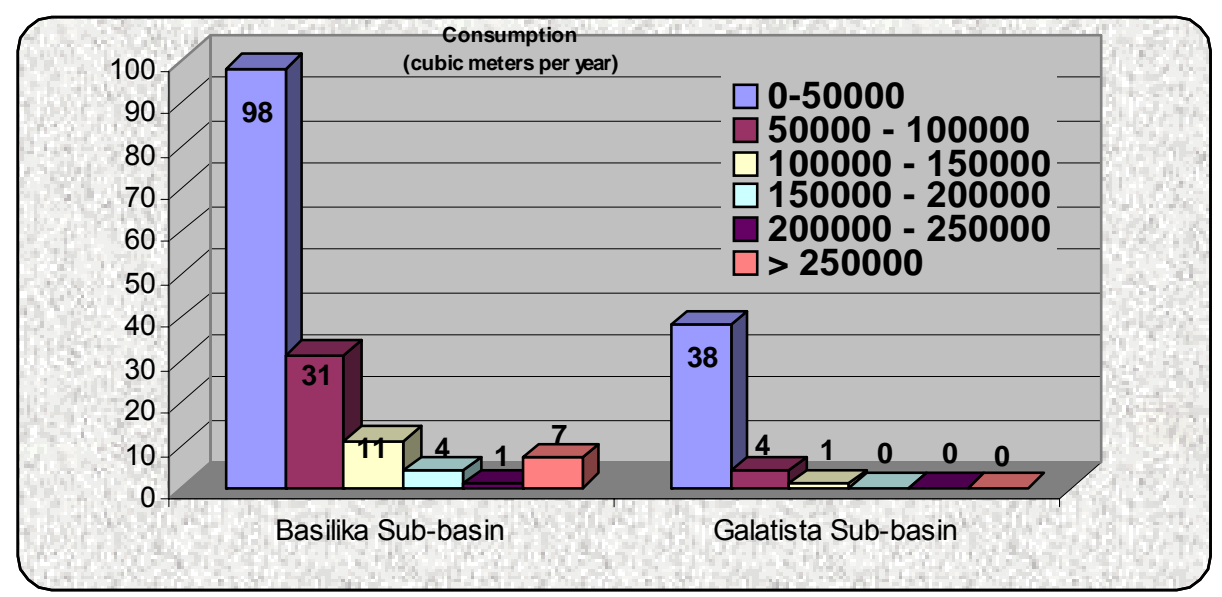

Figure 4. Column Diagram showing the distribution of consumption by the known wells in Anthemountas river basin

\section{REFERENCES}

1. Latinopoulos P. (2001). Evaluation of water resources of the upper part of Anthemountas river basin. Research project of the Department of Civil Engineers, A.U.T.H.

2. Nagoulis A., ANATOLIKH S.A. (1998). Hydrogeological study, Water balance study of Anthemountas river basin, Prefecture Thessaloniki.

3. Soulios G. (1996). General Hydrogeology, University Studio Press, Thessaloniki, Greece. 